\title{
Implikasi Pelaksanaan Reses Anggota DPRD terhadap Daerah Pemilihan di Kabupaten Nias Selatan
}

\author{
Nalom Siagian', Deskarnial Zagoto², Imelda Bintang Kasih Situmorang3 \\ ${ }^{1}$ Dosen Prodi Adm. Bisnis Fisipol UHN Medan \\ ${ }^{2}$ Staf Dinas Sosial Nias Selatan \\ ${ }^{3}$ Mahasiswa Prodi Adm. Bisnis Fisipol UHN Medan \\ Email: nalom.siagian@uhn.ac.id
}

\section{Article Info \\ Article History \\ Received: 2021-11-20 \\ Revised: 2021-12-15 \\ Published: 2022-01-03}

Keywords: Implications;

Recess Implementation, Member of DPRD

Electoral District

\begin{abstract}
This study examines the implications of the implementation of recess for members of the DPRD in the Electoral District in South Nias Regency with the aim of describing the implementation of a recess, describing the implications of implementing a recess in the electoral district, to find out and describe the benefits of implementing a recess for members of the DPRD in South Nias Regency as well as to describe the implications of implementing a recess. to the constituency. The method used in this research is a descriptive qualitative research method with informants from the Leadership Elements and Members of the DPRD of South Nias Regency and the community as constituents in the electoral district. The data analysis technique used in this research is the interactive analysis of the Miles and Huberman model. namely: Data Collection, Data Reduction, Data Presentation and Conclusion Drawing, the results obtained include, the dynamics of the DPRD recess period of South Nias Regency showing symptoms of being less productive for improving legislative performance. The results of the recess have not been fully documented and are not structured so that they cannot be used as a guide in the preparation of the South Nias District Government program. The absorption of people's aspirations through the recess by members of the DPRD of South Nias Regency has only become a routine mechanism without meaning. The reality on the ground shows that the results and realization of the recess of DPRD members are not accommodated so that people do not feel the realization of the recess as a forum for their aspirations.
\end{abstract}

\begin{tabular}{l} 
Artikel Info \\
\hline Sejarah Artikel \\
Diterima: 2021-11-20 \\
Direvisi: 2021-12-15 \\
Dipublikasi: 2022-01-03
\end{tabular}

Kata kunci: Implikasi; Pelaksanaan Reses; Anggota DPRD; Daerah Pemilihan.

\begin{abstract}
Abstrak
Penelitian ini mengkaji mengenai Implikasi Pelaksanaan Reses Anggota DPRD Terhadap Daerah Pemilihan Di Kabupaten Nias Selatan dengan tujuan untuk mendeskriptifkan pelaksanaan reses, mendeskripsikan implikasi pelaksanaan reses terhadap daerah pemilihan, untuk mengetahui dan mendeskripsikan adanya manfaat pelaksanaan Reses Anggota DPRD Kabupaten Nias Selatan serra mendeskripsikan adanya implikasi pelaksaan reses terhadap daerah pemilihan. Metode yang digunakan dalam penelitian ini adalah metode penelitian kualitatif deskriptif dengan informaan Unsur Pimpinan dan Anggota DPRD Kabupaten Nias selatan dan masyarakat sebagai konstituen di daerah pemilihan. Teknik analisis data yang digunakan dalam penelitian ini adalah analisis interaktif model Miles dan Huberman. yaitu: Pengumpulan Data, Reduksi Data, Penyajian Data dan Penarikan Kesimpulan, hasil yang diperoleh diantaranya, Dinamika masa reses DPRD Kabupaten Nias selatan menunjukkan gejala kurang produktif bagi peningkatan kinerja legislatif. Hasil reses belum terdokumentasikan secara utuh dan tidak terstruktur sehingga kurang dapat dijadikan pegangan dalam penyusunan program Pemerintah Daerah Kabupaten Nias Selatan. Penyerapan aspirasi rakyat melalui reses oleh anggota DPRD Kabupaten Nias Selatan hanya menjadi mekanisme rutin tanpa makna, Kenyataan di lapangan menunjukkan bahwa hasil dan realisasi reses anggota DPRD tidak terakomodir sehingga masyarakat tidak merasakan realisasi dari reses sebagai wadah aspirasi mereka.
\end{abstract}

\section{PENDAHULUAN}

Kedudukan Dinas Sosial adalah sebagai instansi atau organisasi publik yang melaksanakan tugas pemerintah daerah di bidang social. Bantuan sosial adalah pemberian bantuan dari pemerintah kepada individu, keluarga, kelompok atau dapat dikatakan masyarakat. sifat bantuan ini dapat dikatakan tidak secara terus-menerus dan selektif. Tujuan dari program bantuan sosial (Bansos) tidak lain hanya untuk dapat membantu masyarakat yang berpendapatan rendah sehingga dicatat dan dizinkan untuk dapat menerima bantuan sosial tersebut dimana untuk dapat menambah bantuan terhadap masyarakat 
tersebut. Kementerian Koordinator Bidang Pembangunan Manusia dan Kebudayaan (Kemenko PKM) bertanggung jawab melakukan koordinasi dan pengendalian pelaksanaan Program Perlindungann Sosial (Social Protection), dimana kebijakan program bantuan sosial tersebut dapat berupa uang tunai ataupun berupa sembako. Secara filosofis Negara bertanggung jawab dalam pemenuhan kebutuhan dasar hak asasi manusia. Perlindungan sosial untuk masyarakat miskin/rentan miskin yang telah ditetapkan adalah penduduk dengan tingkat pendapatan rendah. Kebijakan Program Bantuan Sosial (Bansos) bagi masyarakat berpendapatan rendah juga merupakan bagian dari sistem ketahanan pangan nasional yang dilaksanakan dalam rangkaian upaya mencapai kemandirian dan kedaulatan pangan. Karena pangan adalah salah satu dari hak asasi manusia dan sebagai komoditas strategis yang dilindungi oleh Undang-undang Dasar Negara Republik Indonesia Tahun 1945.

Dengan adanya program ini maka akan dapat meringankan beban masyarakat yang kurang mampu dalam memenuhi kebutuhan pokok tersebut. Namun, dalam proses program bantuan sosial (Bansos) tersebut diperlukan rancangan atau persiapan dalam proses pelaksanaannya dimana pemerintah juga terlebih dahulu harus melihat atau mendata masyarakat yang kurang mampu sehingga pemerintah juga dapat mengambil tindakan dalam proses pelaksanaanya. Dalam bantuan soisal ini juga pemerintah harus benar-benar memperhatikan kriteria penerima bansos yakni masyarakat yang memiliki pendapatan yang rendah serta masyarakat yang mengalami kekurangan dalam penyediaan kebutuhan pokok rumah tangga. Sehingga dalam pelaksanaan program bantuan sosial nantinya berjalan dengan baik dan sesuai dengan prosedur yang sudah ada. Mengingat bantuan sosial dapat berupa sembako maupun uang tunai maka pemerintah juga harus memilih salah satu yang memang pilihan yang terbaik seperti dalam pelaksanaan bantuan sosial akan lebih baik jika bantuan sosial tersebut berupa bantuan uang tunai yang dimana anggaran bantuan sosial dari atas itu pula yang akan diberikan kepada masyarakat. Karena untuk mengatasi terjadinya hal yang tidak diinginkan seperti adanya korupsi atau penggelapan uang.

Di tengah berbagai perubahan yang terjadi di Indonesia baik perubahan politik maupun pemerintahan menyebabkan terjadinya perubahan paradigma khususnya pada Sistem Adminis- trasi Negara. Dengan berlakunya Undang undang Nomor 23 Tahun 2014 tentang Pemerintahan Daerah, Penyelenggaraan Otonomi Daerah dilaksanakan dengan memberikan kewenangan yang luas, nyata dan bertanggungjawab kepada daerah. Pemberian kewenangan yang luas kepada daerah memerlukan koordinasi dan pengaturan untuk lebih mengharmonisasikan dan menyelaraskan pembangunan baik pembangunan daerah maupun antar daerah yang penjabarannya diatur dalam Undang-undang Nomor 25 Tahun 2005 tentang Sistem Perencanaan Pembangunan Nasional. Di dalam Undangundang Nomor 25 Tahun 2005 tersebut ditetapkan bahwa Kabupaten atapun Kota harus memiliki Rencana Pembangunan Jangka Menengah (RPJM) yang menjadi acuan pembangunan masa 5 (lima) tahun kedepan.

Untuk meningkatkan efisiensi dan efektifitas program serta mampu eksis dan unggul dalam persaingan yang semakin ketat dalam lingkungan yang berubah sangat cepat dewasa ini, maka suatu instansi pemerintah harus terus menerus melakukan perubahan ke arah perbaikan. Perubahan tersebut harus disusun dalam suatu tahapan yang konsisten dan berkelanjutan, sehingga dapat meningkatkan akuntabilitas dan kinerja yang berorientasi kepada pencapaian hasil, hal yang tidak dapat dipisahkan dari perubahan paradigma yaitu pembangunan yang menekankan pada peningkatan keterlibatan stakeholder dalam penyusunan perencanaan pembangunan yang memiliki makna aspiratif / bottom-up yang tinggi dalam kehidupan demokrasi tanpa terlepas dari aspek nasional, akseptabel, efisien, efektif dan berkelanjutan. Sebagai apresiasi dalam mewujudkan visi dan misi Pemerintah Kabupaten Nias Selatan, Dinas Sosial dan Pemberdayaan Masyrakat Kabupaten Nias Selatan menjabarkan visi dan misi tersebut dalam Rencana Strategis Tahunan 2016 - 2021. Rencana strategis ini menggambarkan pilihan program dan kegiatan yang dapat dan harus dilaksanakan oleh jajaran Dinas Sosial dan Pemberdayaan Masyarakat Kabupaten Nias Selatan yang mencakup kegiatan dan sasaran yang mempunyai daya dorong kuat dan strategis terhadap pencapaian program pembangunan Kabupaten Nias Selatan.

Kinerja instansi pemerintah sering menjadi sorotan masyarakat, terutama sejak timbulnya iklim yang lebih demokratis dalam tatanan kehidupan masyarakat. Masyarakat mulai mempertanyakan akan nilai yang akan mereka peroleh atas pelayanan yang dilakukan oleh aparatur 
pemerintah, walaupun telah banyak anggaran dihabiskan untuk pembangunan, nampaknya masyarakat belum puas atas kualitas pelayanan jasa maupun barang (pembangunan) yang di berikan oleh pemerintah Kabupaten Nias Selatan.

Untuk meningkatkan kepercayaan dan partisipasi masyarakat kepada pemerintah, maka Dinas Sosial sebagai pengelola bidang sosial yang bermuara pada kualitas pelayanan aparatur kepada masyarakat harus membuat suatu perencanaan stratejik dimana maksud dan tujuannya adalah untuk melihat proses yang berorientasi pada hasil yang ingin dicapai dalam lima tahun kedepan dengan memperhitungkan potensi, peluang dan kendala yang ada atau mungkin timbul, Rencana Stratejik mengandung Visi, Misi, Tujuan, Sasaran, untuk mencapai tujuan dan Sasaran yang meliputi Kebijakan, Program dan Kegiatan yang realistis dengan mengantisipasi perkembangan masa depan sehingga pada akhirnya akan bermanfaat bagi masyarakat.

Rencana Strategis Satuan Kerja Perangkat Daerah (Renstra-SKPD) haruslah mengacu pada isu strategis yang mendukung Visi dan Misi Bupati Nias Selatan yang diterjemahkan dalam Visi dan Misi Dinas Sosial memuat strategi dan kebijakan, tujuan dan sasaran, program dan menggambarkan indikasi kegiatan dengan mengantisipasi perkembangan masa depan sesuai dengan tugas dan fungsi kerja Dinas Sosial, yang disusun dengan berpedoman pada rumusan Rencana Pembangunan Jangka Menengah Daerah (RPJMD) dan bersifat Indikatif, sehingga pada akhirnya akan berdampak positif untuk mencapai sasaran dan tujuan SKPD .

Penjabaran Rencana Strategis (RenstraSKPD) adalah Rencana Kerja (Renja-SKPD) yang harus mempunyai keselarasan rumusan substansi yang ditekankan pada Rencana Kerja Pemerintah Daerah (RKPD) dan untuk dapat melihat konsistensi antara Renstra-SKPD dan RenjaSKPD, maka dokumen Renja-SKPD haruslah mempunyai keterkaitan pokok-pokok isi dari Renstra-SKPD tersebut seperti isu strategis, Visi, Misi, strategi dan kebijakan, maupun tujuan dan sasarannya sedangkan program SKPD haruslah mempedomani rumusan program RPJMD. Kegiatan yang direncanakan pada Renja-SKPD harus juga berpedoman pada indikasi kegiatan pada Renstra-SKPD dan mempunyai keselarasan rumusan substansi yang ditekankan pada RKPD

Penyelenggaraan kesejahteraan sosial merupakan kewajiban dari setiap Pemerintah kepada warga masyarakatnya, namun demikian penyel- enggaraan kesejahteraan sosial bukanlah suatu hal yang mudah karena permasalahan yang terjadi di dalamnya sangat kompleks. Sebagaimana kita ketahui bahwa garapan dari Dinas Sosial Kabupaten Nias Selatan ialah para Penyandang Masalah Kesejahteraan Sosial (PMKS) yang sebagian besar di antara mereka merupakan penduduk miskin yang tidak mampu menjalankan peran dan fungsi sosialnya di masyarakat secara wajar. Penyebab terjadinya berbagai permasalahan sosial yang diderita oleh para PMKS ini sangat bervariasi, hal tersebut kita dapat kelompokkan ke dalam 2 (dua) kelompok besar yaitu yang dikarenakan faktor eksternal dan internal. Faktor eksternal diantaranya kejadian bencana alam/sosial, kebijakan pemerintah, serta pengaruh lingkungan, sedangkan faktor internal diantaranya tingkat pendidikan yang rendah serta keterbatasan fisik atau mental yang dimiliki oleh seorang individu.

Tuntutan masyarakat terhadap pemerintah terkait pelayanan dalam bidang kesejahteraan sosial ini sangatlah tinggi karena selain dirasakan langsung oleh masyarakat juga berhasil atau tidaknya suatu proses pembangunan yang dilakukan oleh suatu pemerintahan ialah semakin berkurangnya jumlah penduduk miskin pada daerah tersebut atau dengan kata lain warga masyarakatnya sejahtera, tuntutan terhadap kinerja Dinas Sosial Kabupaten Nias Selatan tidak hanya muncul dari masyarakat akan tetapi juga dari pihak pemerintah pusat maupun provinsi, hal tersebut tercermin dengan diterbitkannya Peraturan Menteri Sosial Republik Indonesia tentang Standar Pelayanan Minimal bidang Kesejahteraan Sosial, dimana tujuan dari SPM tersebut ialah menselaraskan penyelenggaraan pembangunan bidang kesejahteraan sosial sekaligus dalam rangka percepatan penuntasan permasalahan sosial di seluruh daerah di Indonesia sehingga menuntut pihak pemerintah daerah untuk mengalokasikan anggaran serta sumber daya lainnya secara memadai guna mencapai target Standar Pelayanan Minimal.

Nias Selatan merupakan kabupaten dengan urutan ke-14 jumlah penduduknya di provinsi Sumatera Utara setelah Labuhan Batu Utara dan Tapanuli Tengah. Menurut hasil pencacahan lengkap Sensus Penduduk 2010 penduduk Nias Selatan berjumlah 289.708 jiwa dengan 60.178 rumah tangga. Jumlah penduduk ini dengan persentase terhadap provinsi sebesar 2,2 persen. Jika dibandingkan dengan seluruh kabupaten/ kota di Kepulauan Nias, Kabupaten Nias Selatan 
merupakan jumlah penduduk terbesar. Pada hasil estimasi (proyeksi penduduk), jumlah penduduk Nias Selatan keadaan 2019 adalah 319.902 jiwa. Kepadatan penduduk Nias Selatan tahun 2018 adalah 128 jiwa per km2.

Tabel 1. Jumlah Penduduk Miskin Kabupaten Nias Selatan

\begin{tabular}{ccc}
\hline Tahun & Jumlah & Persentase (\%) \\
\hline 2012 & 56940 & 19,05 \\
\hline 2013 & 56960 & 18,83 \\
\hline 2014 & 54460 & 17,81 \\
\hline 2015 & 58970 & 19,05 \\
\hline 2016 & 57750 & 18,60 \\
\hline 2017 & 57950 & 18,48 \\
\hline 2018 & 52700 & 16,65 \\
\hline 2019 & 52510 & 16,45 \\
\hline \multicolumn{3}{c}{ Sumber : BPS Kabupaten Nias Selatan }
\end{tabular}

Dari tabel diatas dapat disimpulkan bahwa masayarakat Kabupeten Nias Selatan masih memerlukan bantuan sosial dari pemerintah dalam hal dinas sosial. Hal ini terbukti pada tahun 2012 penduduk Kabupaten Nias Selatan sebanyak 19, $05 \%$ masih tergolong miskin, tahun 2013 sebanyak 18, $83 \%$, tahun 2014 sebanyak 17, $81 \%$, 2015 sebanyak 19,05\%, tahun 2016 sebanyak 18, 60 \%, tahun 2018 sebanyak 16, 65 \% dan tahun 2019 sebanyak 16, 45 , Kemiskinan sebagai dampak permasalahan ekonomi dalam pembangunan wilayah akan menjadikan daerah tersebut masuk dalam status daerah tertinggal. Perpres Perpres RI No. 2 Tahun 2015 tentang RPJMN Tahun 2015-2019 telah menetapkan daerah-daerah tertinggal di beberapa provinsi termasuk di Sumatera Utara yaitu: Kabupaten Nias, Kabupaten Nias Selatan, Kabupaten Nias Barat dan Kabupaten Nias Utara. Kriteria penetapan daerah tertinggal dalam RPJMN tersebut adalah berdasarkan perekonomian masyarakat, sumber daya manusia, sarana dan prasarana, kemampuan keuangan daerah, aksesibiltas serta karakteristik daerah.

Bantuan sosial beras dari Kementerian Sosial (Kemensos) Republik Indonesia (RI) disalurkan oleh Dinas Sosial Kabupaten Nias Selatan (Nisel) kepada keluarga penerima manfaat di setiap kecamatan wilayah Kabupaten Nias Selatan. Penyaluran bansos tersebut dilaksanakan sejak tanggal 09 Agustus 2021 yang diawali dengan penyerahan secara simbolis oleh Kepala Dinas (Kadis) Sosial Kabupaten Nias Selatan.

Bansos beras yang disalurkan sebanyak 338,1 ton dengan penerima 33.810 KPM (Keluarga Penerima Manfaat) dari Cadangan Beras Pemeri- ntah (CBP) untuk Program Keluarga Harapan (PKH) dan Bantuan Pangan Non Tunai (BPNT) maupun program Bantuan Sosial Tunai (BST) dengan sasaran 35 Kecamatan di wilayah Kabupaten Nias Selatan. Setiap KPM menerima sebanyak $10 \mathrm{~kg}$ beras berkualitas medium dari Cadangan Beras Pemerintah (CBP). Program Bantuan Beras di Nias Selatan dilaksanakan atas Pemberlakuan Pembatasan Kegiatan Masyarakat Tahun 2021, meliputi sebanyak 15.596 KPM PKH, sebanyak 8.416 KPM BPNT/Sembako dan sebanyak 9.798 KPM BST yang tersebar di masing-masing kecamatan.

Berdasarkan uraian latar belakang di atas, maka rumusan masalah yang akan diteliti dalam penelitian ini adalah "Bagaimana Langkah Strategis Dinas Sosial Dalam Menanggulangi Masalah Sosial Di Kabupaten Nias Selatan"?.

\section{METODE PENELITIAN}

Penelitian ini menggunakan metode penelitian kualitatif dengan pendekatan deskriptif dengan Informan adalah narasumber yang memiliki keahlian serta pemahaman yang terbaik mengenai isu-isu tertentu memahami menanggulangi masalah sosial di Kabupaten Nias Selatan, yaitu Kepala Dinas Sosial Kabupaten Nias Selatan, menjadi informan kunci dan masyarakat Kabupaten Nias Selatan yang menerima bantuan sosial atau manfaat dari progaram Dinas Sosial Kabupaten Nias Selatan, Jenis data yang diperlukan dalam penelitian ini adalah Data Primer dan Data Sekunder dengan Teknik analisis data yang digunakan adalah:

1. Mengolah dan mempersiapkan data untuk dianalisis.

2. Membaca keseluruhan data.

3. Menganalisis dengan detail dengan mengkoding data.

4. Menerapkan proses coding

5. Menunjukkan bagaimana deskripsi dan tematema ini akan disajikan kembali dalam narasi/ laporan kualitatif.

6. Menginterpretasikan atau memaknai data

\section{HASIL DAN PEMBAHASAN}

A. Hasil Penelitian

Kabupaten Nias Selatan berada di sebelah Barat Pulau Sumatera jaraknya \pm 92 mil laut dari kota Sibolga (Kabupaten Tapanuli Tengah), Kabupaten Nias Selatan berbatasan dengan Kabupaten Nias disebelah utara, kepulauan Mentawai (Propinsi Sumatera Barat) disebelah selatan, Kabupaten Mandailing Natal dan Pulau-pula Mursala (Kabupaten 
Tapanuli Tengah) disebelah timur dan disebelah baratnya berbatasan dengan Samudra Hindia. Ibukota Kabupaten Nias Selatan adalah Telukdalam yaitu $\pm 120 \mathrm{~km}$ dari kota Gunungsitoli (Kabupaten Nias). Luas wilayah Kabupaten Nias Selatan adalah $\pm 1.825,2 \mathrm{~km} 2$ memiliki 102 buah gugusan pulau dan dalam pembagian Administratif pemerintahannya, Kabupaten Nias Selatan terdiri dari 35 kecamatan, dengan 459 desa dan 2 kelurahan yang terbentuk pada tahun 2003. Kedua kelurahan tersebut yaitu Kelurahan Pasar Telukdalam dan Kelurahan Pasar Pulau Tello.

Kemiskinan di Kabupaten Nias Selatan merupakan suatu permasalahan yang sangat penting untuk diatasi, Pemerintah Kabupaten Nias Selatan sebagai pemilik tanggung jawab di Kabupaten Nias Selatan telah melakukan berbagai usaha dalam mengatasi kemiskinan yang ada di daerahnya dengan membuat berbagai kebijakan sebagai upaya dalam percepatan penanggulangan kemiskinan. Dinas Sosial merupakan salah satu bagian dari lembaga pemerintah Kabupaten Nias Selatan yang memiliki fokus dalam pembangunan kesejahteraan social. Hal tersebut sebagaimana tercantum dalam Undang-Undang Nomer 11 Tahun 2009 yaitu tentang Kesejahteraan Sosial pasal 1 ayat 2 yang menyatakan bahwa "Penyelenggaraan Kesejahteraan Sosial adalah upaya yang terarah, terpadu, dan berkelanjutan yang dilakukan Pemerintah, Pemerintah Daerah, dan masyarakat dalam bentuk pelayanan sosial guna memenuhi kebutuhan dasar setiap warga negara yang meliputi rehabilitasi sosial, jaminan sosial, dan pemberdayaan sosial, serta perlindungan sosial. Pada pelaksanaan penyelenggaraan kesejahteraan sosial yang dilakukan Dinas Sosial Kabupaten Nias Selatan terdapat beberapa fokus salah satunya yaitu mengatasi kemiskinan.

Dinas sosial Kabupaten Nias Selatan dalam melaksanakan berbagai program untuk mengatasi kemiskinan melalui sebuah seksi yang terdapat dalam bidang Penyandang Masalah Kesejahteraan Sosial Lansia, Fakir Miskin, dan Korban Bencana yaitu pada seksi pelayanan dan rehabilitasi sosial fakir miskin, dimana pada seksi tersebut menjalankan sebuah kebijakan yaitu pelayanan sosial terhadap fakir miskin Berdasarkan hasil wawancara peneliti dengan Kepla Dinas Sosial ibu Intansani Haria,S.E.,MM, bahwa dalam pelayanan sosial fakir miskin di Dinas Sosial
Kabupaten Nias Selatan ada dua program yaitu Program fasilitasi manajemen usaha bagi keluarga miskin Program pengadaan sarana dan prasarana pendukung bagi usaha keluarga miskin dengan pemberian bantuan pokok bagi fakir miskin. Kedua program tersebut merupakan beberapa program andalan yang dilaksanakan Dinas Sosial Kabupaten Nias Selatan. Namun, dengan adanya situasi pandemi virus corona 19, maka program tersebut tidak berjalan sesuai dengan yang di harapkan karena pemerintah memusatkan perhatian yang serius untuk mengatasi dampak negatif akibat pandemi 19 tersebut.

Salah satu dasar pelaksanaan program bantuan Dinas sosial Kabupaten Nias selatan mengacu pada Radiogram Mendagri RI Nomor 511 2/4014/SJ untuk Bupati/Wali Kota seluruh Indonesia terkait Penyaluran Beras bagi KPM PKH dan BST. Berikutnya, Peraturan Direksi Perum Bulog Nomor PD11/D0000/07/2021 tentang Penyediaan dan Pendistribusian Beras Cadangan Beras Pemerintah (CBP) untuk Program Bantuan Beras Masa PPKM 2021. Tujuannya untuk mengurangi beban pengeluaran KPM melalui pemenuhan sebagian kebutuhan pangan beras selama PPKM dalam menghadapi Pandemi Covid-19. Dengan interval waktu penyalurannya mulai Agustus sampai dengan September 2021, sesuai jadwal yang sudah ditentukan. Pelaksana kegiatan ditunjuk oleh Pemerintah Pusat, yakni Perum Bulog DNR Corporation, transporter yang ditunjuk Kementerian Sosial (Kemensos), didampingi para pendamping PKH untuk memonitor kepada KPM PKH. Untuk KPM BPNT dan BST akan dibantu oleh Tenaga Sosial Kecamatan.

Selanjutnya peneliti melakukan wawancara dengan Kepala Dinas sosial Kabupaten Nias selatan ibu Intansani Haria,S.E.,MM, tentang bentuk pelaksanaan pemberian bantuan sosial bagi masyarakat miskin di Kabupaten Nias Selatan mengatakan bahwa:

"Bantuan sosial dari Kementerian Sosial Republik Indonesia disalurkan oleh Dinas Sosial Kabupaten Nias Selatan kepada keluarga penerima manfaat di setiap kecamatan wilayah Kabupaten Nias Selatan.

"salah satu bentuk bantuan sosial berupa beras yang disalurkan sebanyak 338,1 ton dengan penerima 33.810 KPM (Keluarga Penerima Manfaat) dari Cadangan Beras Pemerintah (CBP) untuk Program Keluarga 
Harapan (PKH) dan Bantuan Pangan Non Tunai (BPNT) maupun program Bantuan Sosial Tunai (BST) dengan sasaran 35 Kecamatan di wilayah Kabupaten Nias Selatan, meliputi sebanyak 15.596 KPM PKH, sebanyak 8.416 KPM BPNT/Sembako dan sebanyak 9.798 KPM BST yang tersebar di masing-masing kecamatan".

Sesuai pengamatan peneliti dilapangan dengan hasil wawancara terhadap salah satu warga di kelurahan Teluk Dalam, dalam penjelasannya mengatakan:

"ya, betul saya salah satu penerima bantuan KPM, setiap peserta KPM menerima sebanyak $10 \mathrm{~kg}$ beras berkualitas medium dari Cadangan Beras Pemerintah (CBP)".

Berdasarkan hasil pengamatan peneliti, bahwa betul masyarakat menerima Bantuan sosial berupa beras beras yang didistribusikan oleh dinas sosial Kabupaten Nias selatan yang bersumber dari pemerintah pusat melalui Bulog dan pelaksanaan penyaluran oleh masing-masing desa di setiap kecamatan. Bantuan berupa beras ini adalah merupakan kompensasi dari penerapan PPKM Darurat. Melalui penyaluran ini, Kepala Dinas Kabupaten Nias selatan mengharapkan kepada para penerima manfaat agar benar-benar memanfaatkan bantuan tersebut untuk memenuhi kebutuhan di masa PPKM Darurat. Serta diharapkannya dapat mematuhi aturanaturan di masa PPKM dengan cara membatasi kegiatan di luar rumah dan taat protokol kesehatan, yakni: menjaga jarak, memakai masker, mencuci tangan, menjaga imun, serta menjaga iman.

Berdasarkan pengamatan peneliti di lokasi penelitian kecamatan yang berbeda, bahwa pada tahun 2020 beberapa program target penanggulangan kemiskinan di Kabupaten Nias Selatan telah berlangsung, di antaranya Program Keluarga Harapan (PKH), Bantuan Sosial Non Tunai, Rehabilitasi Sosial Rumah Tidak Layak Huni (Rutilahu), Kelompok Usaha Bersama (Kube) dan Kewirausahaan Sosial, Hasil wawancara lanjutan dengan Kadis Sosial Nias Selatan ibu Intansani Haria, tentang berapa jumlah kepala keluarga yang menerima bantuan sosial di Kabupaten nias selatan:

"Pada Tahun 2019 lalu, Kementerian telah menetapkan Kabupaten Nias Selatan sebagai penerima Program Keluarga Harapan (PKH)".
"Pada tahun 2019 ada 13.000 KK yang penerima PKH dan pada tahun 2020 naik menjadi $14.000 \mathrm{KK}$ dengan jumlah dana sekitar Rp 70 miliar. "Dana ini sama dengan tahun sebelumnya, hanya saja penerima manfaatnya bervariasi sesuai dengan ketentuan Kementerian Sosial."

Lebih lanjut peneliti bertanya, apakah bantuan yang disalurkan hanya dalam bentuk bantuan beras atau masih ada bentuk bantuan yang lain.

"Selanjutnya, beberapa program lainnya seperti Bantuan Sosial non tunai, dengan jumlah penerima sebanyak 28.954 kepala keluarga dengan nilai Rp. 150 ribu/bulan atau sekitar Rp. 52 miliar/tahun. Sebelumnya, bantuan sosial non tunai tersebut, cuma Rp 110.000/KK setiap bulannya".

"Berikutnya adalah penanganan 26 masalah penyandang kesejahteraan sosial, dengan pemberian bantuan pangan seperti di Panti Asuhan, distabilitasi, Lansia terlantar, bencana alam dan sebagainya".

"Seterusnya, program Rehabilitasi Sosial Rumah Tidak Layak Huni (Rutilahu) jumlah penerima manfaat sebanyak 15 unit. Dan program Kelompok Usaha Bersama (KUBE) dari ratusan kelompok yang sudah diajukan di Kementerian, hanya 50 kelompok yang di setujui".

"saat ini telah dilakukan perekrutan pendamping lokal oleh Kementerian dan akan mengikuti pembekalan guna memverifikasi data kelompok".

"bahwa penerima manfaat KUBE pada tahun 2020, di Kepulauan Nias hanya Kabupaten Nias Selatan yang mendapatkan kuota tersebut".

Berdasarkan hasil pengamatan peneliti dilapangan, bahwa betul masyarakat di beberapa kecamatan telah mendapat bantuan sosial yang disalurkan oleh Dinas Sosial kabupaten Nias selatan, dan dibuktikan oleh beberapa masyarakat melalui wawancara peneliti sebagan masyarakat.

"ya, betul...bapak, kami keluarga yang tidak mampu sangat bersyukur bahwa pemerintah kabupaten Nias Selatan memperhatikan kehidupan masyarakatnya dengan menerima bantuan sebanyak Rp 150.000 per bulan dan sudah kami terima beberapa bulan melalui kantor POS".

Terkait bantuan sosial seperti penanganan 
26 masalah penyandang kesejahteraan sosial, dengan pemberian bantuan pangan seperti di Panti Asuhan, distabilitasi, Lansia terlantar, bencana alam yang diutarakan Kepala Dinas Intansani Haria, peneliti menelusuri ke masyarakat dan lembaga yang menerima manfaat bantuan tersebut ternyata betul, sesuai hasil wawancara peneliti.

"Terimakasih yang sebesar-besarnya kami sampikan kepada ibu Intansani Haria yang langsung menyampaikan bantuan tersebut ke yayasan kami, sehingga lembaga ini bisa terbantu dalam hal menanggulagi keperluan anak-anak yang kami asuh dan bantuan fisik bangunan bisa kami nikmati. Tidak terbalaskan memang bapa...apa yang sudah kami rasakan. Dan memang bukan cuman kami yang merasakan, semua yang menghuni di lembaga ini ikut juga merasakan. Ada anak-anak yang yatim-piatu, ada penyangdang dissabilitas dan bahkan ada orang tua yang membutuhkan bantuan lembaga ini dan tinggal disini".

"dan kami tau diluar sana juga banyak yang menerima manfaat bantuan sosial seperti ini seperti yang kena bencana, pokoknya mantaplah dari dinas sosial kita".

Terkait dengan program bantuan rehabilitasi rumah tidak layak huni (Rutilahu) dengan jumlah penerima manfaat sebanyak 15 unit dan program Kelompok Usaha Bersama (KUBE) dari ratusan kelompok yang sudah diajukan Dinas sosial kabupaten Nias Selatan ke Kementerian, peneliti melakukan pengamatan terhadap kelompok masyarakat dan ternyata benar program tersebut sudah terlaksana yang tersebar di beberapa daerah. Hal ini diakui oleh kelompok masyarakat yang menerima dengan direhapnya rumah yang dihuni walaupun dengan keadaan yang sederhana sesuai anggaran yang diberlakukan untuk setiap rumah sebanyak 15 unit.

"ya betul, kami salah satu penerima manfaat perbaikan rumah bantuan pemerintah Kabupaten. Di daerah ini ada dua rumah tangga yang dapat, katanya bertahap mungkin kawan-kawan keluarga yang lain akan mendapatnya lain waktu sesuai usulan kepala desa kami. Ya.... bersabarlah, kapan itu datang, kan di daerah lain juga dipikirkan pemerintah, yang saya tau ada 35 kecamatan yang mengharapkan bantuan ini. Waktu kami diwawancarai hanya ada yang mendapat 15 keluarga, berarti belum semua masyarakat yang butuh dapetan".
Terkait program Kewirausahaan Sosial, Kadis Sosial menyatakan bahwa kedepannya akan diberdayakan penerima manfaat agar jangan hanya penerima saja, akan tetapi mampu berwira usaha memulai program seperti KUBE. Sehingga kedepannya bisa mandiri dan segera keluar dari status miskin.

"Saya memastikan bahwa setiap penerima manfaat dipastikan datanya harus ada di data base data terpadu kesejahteraan sosial (DTKS) dan kita berharap, operator di setiap desa benar-benar mendata warga yang dianggap keluarga tidak mampu".

Hasil wawancara peneliti dengan ibu Ritikasih Zagoto, SKM, MM selaku Kepala Bidang Pemberdayaan Fakir Miskin Kabupaten Nias selatan mengatakan bahwa :

"Dinas Sosial Kabupaten Nias Selatan memastikan jumlah penerima bantuan sosial di kabupaten tersebut sudah melalui tahap verifikasi. Untuk itu, masyarakat diminta dapat menyampaikan keluhan secara langsung kepada Dinas Sosial Kabupaten Nias Selatan bila mengalami permasalahan terkait bantuan sosial tersebut".

Lebih lanjut dijelaskan, untuk mengumpulkan data penerima bansos, pihaknya sudah melalui mekanisme yang ditetapkan. Dimana, data dikumpulkan oleh operator desa dan diverifikasi secara langsung melalui dialog dengan calon penerima bantuan.

"Melalui hasil dialog operator desa dengan keluarga, baru dibawa ke musyawarah desa, hasilnya ditandatangani aparat desa, baru diekspor ke aplikasi SIKS-NG (Sistem Informasi Kesejahteraan Sosial-Next Generation) kabupaten Nias Selatan. calon penerima bantuan tersebut akan diusulkan ke Kementerian Sosial RI. Nantinya, Kemensos yang akan menetapkan siapa yang berhak mendapatkan bantuanbantuan sosial tersebut".

"Ketika data sudah dikumpulkan, jangan terlalu berharap pada saat itu juga menerima bansos, karena harus melalui proses misalnya tahun 2021 di Nisel kuotanya ada 20.503 KPM (Keluarga Penerima Manfaat)".

Selanjutnya ia menghimbau agar KPM segera ke Dinas Kependudukan dan Catatan Sipil Kabupaten Nias Selatan untuk melakukan pemadanan NIK (Nomor Induk Kepend- 
udukan) serta melakukan perekaman ke Dinsos Kabupaten Nias Selatan melalui operator SIKS-NG untuk perbaikan data, sehingga bansos berikutnya dapat disalurkan secara tepat.Ia juga menegaskan agar para KPM memanfaatkan bansos sesuai peruntukannya dalam membantu perekonomian masyarakat, kemudian penliti bertanya tentang apa yang menjadi kriteria bagi masyarakat calon penerima bantuan social di Kabupaten Nias Selatan, dan apakah pelaksanaan sudah berjalan dengan efektif.

"Yang menjadi kriteria dalam penerimaan bantaun sosial yaitu masyarakat yang berpenghasilan rendah, serta masyarakat yang kurang mampu".

"Sesuai pantau kami sejauh ini pelaksanaan program bantuan sosial diseluruh wilayah Kabupaten Nias Selatan sudah berjalan dengan baik dan efektif sesuai aturan yang berlaku, karena yang menyalurkan langsung adalah pelaksana di desa masingmasing".

Lebih lanjut peneliti melakukan wawancara dengan warga masyarakat penerima bantuan sosial. Menurut ibu, Apakah data penerimaan bantuan sosial secara terbuka kepada semua masyarakat, penyaluran sudah berjalan dengan baik dan pemerintah sudah memberikan pelayanan yang baik kepada setiap masyarakat saat penyaluran bantuan.

"data penerima bantuan biasanya ada perangkat desa yang mendatangi kita ke rumah untuk mengatakan bahwa kita dapat bantuan dan disuruh mengambil ke balai desa, terkadang data penerima ditempelkan di papan pengumuman".

"menurut saya belum, karena terkadang ada terkadang tidak ada apa, menurut saya bantuan sosial ini belum tepat waktu karena tidak ada tanggal yang ditetapkan untuk mengambil bantuan sosial ini.

"saat pembagian bantuan sosial perangkat desa memberikan pelayanan yang baik, berperan aktif dan memberikan pelayanan yang baik kepada setiap masyarakat".

Selanjutanya peneliti meneruskan mencari informasi dengan masyarakat yang lain tentang manfaat dan yang dirasakan masyarakat dengan adanya bantuan sosial yang diberikan pemerintah.

"sangat bermanfaat karena sangat membantu saya untuk memenuhi kebutuhan seperti beras dan yang lainnya. saya sangat senang dengan adanya bantuan sosial ini karena dapat membantu saya untuk memenuhi kebutuhan pangan saya dengan memberikan bantuan sembako apalagi situasi sekarang semuanya serba sulit bahkan untuk memenuhi kebutuhan pangan pun sulit".

Peneliti melakukan wawancara lanjutan mengenai penyaluran bantuan social seperti apa yang diterima oleh masyarakat miskin dan bagaimana pendapat masyarakat tentang pendistribusikan bantuan social di kabupaten nias selatan.

"bentuk bantuan sosial diberika berupa beras $10 \mathrm{~kg}$, minyak goreng, gula putih, telur ayam. menurut saya dinas sosial Nias selatan sudah berperan dengan baik dalam pendistribusian bantuan sosial,jikapun melalui desa, kan ini sumbernya dari kabupaten yang sangat berperan dengan baik dalam penyaluran bantuan sosial karena dengan adanya program ini sangat membantu masyarakat yang miskin apalagi sejak adanya pandemi inii, untuk memenuhi kebutuhan pangan pun terkadang sulit".

B. Pembahasan

1. Langkah Perencanaan Pendataan Penerima Bantuan Sosial

Berdasarkan pengamatan peneliti di lokasi penelitian, bahwa program pendataan masyarakat penerima bantuan sosial yang ada di kabupaten Nias selatan sudah belum berjalan dengan baik untuk seluruh desa. Walaupun proses pelaksanaannya masih kurang terstruktur bahkan data dalam penerimaan bantuan sosial juga tidak selalu ditempelkan di papan pengumuman, melainkan hanya diberitahukan dari rumah ke rumah oleh pihak pemeritah desa. Penyaluran bantuan sosial ini sudah berjalan dengan baik karena dapat dilihat dari proses penyalurannya juga sudah berjalan dengan baik, walaupun tidak ada jadwal yang jelas atau yang sudah ditentukan oleh pemerintah desa dalam penerimaannya malainkan hanya diberitahukan secara tiba-tiba kepada masyarakat yang mendapat bantuan. Dilihat dari segi keterbukaan data-data calon penerima bantuan sosial juga data tidak terlihat jelas oleh semua masyarakat melainkan hanya pemerintah desa yang tau siapa yang mendapatkan, padahal pada dasarnya data-data atau nama-nama calon penerima 
bantuan sosial sudah seharusnya ditempelkan dipapan pengumuman sehingga terlihat bahwa siapa-siapa saja yang mendapatkan bantuan sosial tersebut. Dengan demikian, yang dilakukan oleh pemerintah malalui desa kurang mendukung dalam kepentingan bersama.

2. Langkah Strategis Penanggulangan Masalah Sosial Di Dinas Sosial Kabupaten Nias Selatan

Pembangunan sosial merupakan sebuah proses perubahan sosial yang terencana, yang dirancang untuk meningkatkan taraf hidup masyarakat, dimana pembangunan yang dilakukan saling melengkapi dengan proses pembangunan ekonomi. Konsep pembangunan sosial bertujuan untuk meningkatkan kesejahteraan sosial. Dimana pendekatan pembangunan sosial lebih berfokus pada peningkatan kemampuan individu, komunitas, dan masyarakat melalui pendidikan, kesehatan, jaminan sosial dan pengentasan masalah kemiskinan. Masalah kemiskinan merupakan masalah yang sangat krusial, sebab sampai sekarang ini masih menggorogoti sandisandi kehidupan masyarakat indonesia. Hal ini disebabkan karena kemiskinan merupakan masalah yang bersifat multidimensional. Jika ditinjau dari segi kebijakan, selama ini kebijakan-kebijakan terkait penanggulangan kemiskinan masih dalam tataran yang artifisial. Persoalan kemiskinan hanya dipandang sebagai kurangnya pendapatan atau bersifat ekonomis (Singh, 2012). Dengan konsepsi semacam ini berimplikasi pada kebijakan atau program yang dibuat hanya menyentuh pada tataran quantifikasi pendapatan dan pengeluaran masyarakat.

Oleh karena itu, salah satu kunci keberhasilan dalam menanggulangi masalah kemiskinan adalah dengan menerapkan konsep pembangunan sosial, karena pembangunan sosial bertujuan meningkatkan kemampuan masyarakat supaya bisa mandiri dalam memenuhi kebutuhan dasar, mengelola masalah-masalah sosial, dan peningkatan peluang berpartisipasi dalam kehidupan bermasyarakat. Selain itu, konsep pembangunan sosial secara konseptual lebih berorientasi pada prinsip keadilan sosial ketimbang pertumbuhan ekonomi.
Menurut Yanagisawa (2011), kesulitan dalam memahami masalah kemiskinan menjadi salah satu faktor yang menyebabkan masalah ini tak kunjung selesai. Berbagai upaya yang dilakukan oleh pemerintah untuk memberantas masalah tersebut, mulai dari pemberian bantuan langsung tunai (BLT), memberikan kredit kepada masyarakat miskin, dan lain-lain, namun masih jauh dari harapan. Kesulitan tersebut terjadi disebabkan dua hal, yaitu pertama, kesulitan dalam mengukur dan mengoperasikan konsep kemiskinan dan kedua, kesulitan dalam menentukan asal usul masalah kemiskinan tersebut.

Pertama, kesulitan mengukur dan mengoperasikan konsep kemiskinan. Hal ini terjadi karena dua hal. Pertama, kemiskinan selalu digambarkan sebagai keadaan seseorang atau kelompok yang tidak mampu memenuhi kebutuhan dasar karena tidak memiliki sumberdaya yang memadai. Ketika konsep ini digunakani untuk mengukur kemiskinan seseorang atau kelompok, maka pertanyaannya adalah bagaimana kita dapat menentukan apa kebutuhan dasar individu atau kelompok. Menurut Karelis dalam Yanagisawa (2014) bahwa kebutuhan dasar manusia bukan hanya berkaitan dengan kebutuhan fisik saja, melainkan kebutuhan non fisik juga termasuk kebutuhan dasar manusia seperti martabat, harga diri, interaksi sosial, kesetiakawan dan sebagainya. Oleh karena itu, dalam mengukur kemiskinan kita tidak hanya memakai indikatorindikator ekonomis semata, melainkan juga memakai indikator yang non ekonomi. Kedua, terkait dengan pengalaman subjektif individu atau kelompok yang berbeda terhadap kondisi kemiskinan.

Hal ini membuat kita kesulitan dalam mengukur dan mengoperasikan konsep kemiskinan kepada individu atau kelompok, karena kemiskinan yang mereka alami bervariasi antara satu orang dengan orang lain atau antara satu kelompok dengan kelompok lain. Menurut Yanagisawa (2014), penyebab pengalaman subjektif yang bervariasi disebabkan adanya wacana sosial ekonomi yang di internalisasi dalam diri mereka. Sehingga mereka memiliki pengalaman yang berbeda terhadap kondisi kemiskinan. Misalnya, budaya Chuuk Mikronesia, dimana orang-orang 
tersebut tidak memiliki air bersih dan listrik, namun mereka tidak merasa dalam kondisi miskin.

Kedua, yaitu kesulitan dalam menentukan asal usul kemiskinan. Dalam konteks ini, terkait dengan pandapat para ahli yang berbeda dalam menentukan faktor-faktor penyebab kemiskinan. Dalam perspektif makro, kemiskinan di pandang sebagai efek dari struktur masyarakat seperti struktur sosial, politik, budaya, dan ekonomi yang bersifat eksploitatif (lihat Cecchini, 2014; Yanagisawa, 2014). Sedangkan dalam perspektif mikro, kemiskinan dipandang sebagai efek dari individu itu sendiri, dimana individu tersebut tidak memiliki jiwa kewirausahaan, malas, berorientasi masa lalu, dan bersifat eksklusif (Yanagisawa, 2014).

Dari penjelasan di atas, menunjukan bahwa masalah kemiskinan merupakan masalah yang bersifat multidimensional (Nugroho, 1999; Yanagisawa, 2011). Di mana semua aspek kehidupan dapat terjangkiti oleh virus ini, baik aspek sosial, politik, ekonomi, budaya bahkan aspek non fisik dari manusia itu sendiri. Menurut Yanagisawa (2014), meskipun sulit untuk mendefinisikan konsep kemiskinan dengan tepat, akan tetapi kita harus mendefinisikannya karena dengan mendefinisikan kita dapat mengidentifikasi faktor-faktor penyebabnya sehingga kita dapat menemukan solusi untuk mengatasinya.

Pembangunan ekonomi merupakan salah satu instrument penting untuk meningkatkan kesejahteraan bagi masyarakat. Ketika meningkatnya pertumbuhan ekonomi maka kesejahteraan masyarakat pun ikut meningkat. Namun dalam kenyataannya, hal ini tidak terbukti. Menurut Wirutomo (2014), bahwa pendekatan pembangunan ekonomi meskipun akan menghasilkan pertumbuhan ekonomi yang tinggi, akan tetapi pendekatan ini tidak menciptakan pemerataan pendapatan masyarakat secara adil. Selain itu, pendekatan ini juga menciptakan pengangguran, kemiskinan, kesenjangan sosial, kerusakan lingkungan, mengindahkan nilai-nilai budaya lokal, dan tidak demokratis atau non partisipan serta mengabaikan pembangunan yang bersifat berkelanjutan (Jones \& Truell, 2012; Bonoli, 2006 dalam Rovny, 2014; UNDP, 1997 dalam Wirutomo, 2014).
Sebagai pendekatan, pembangunan sosial bukanlah sebuah konsep baru, pendekatan ini hadir di akhir 1970 dan sebagai sebuah wacana yang bertujuan untuk menghilangkan beberapa ekses negative dari pembangunan ekonomi yang tidak diinginkan seperti kesenjangan sosial dan ekonomi, disintegrasi sosial dan lain-lain (Zuvekas, 1979 dalam Pillai dan Gupta, 2009; Chua dkk, 2010). Bagi beberapa orang, pembangunan sosial dipahami sebagai pengembangan lembaga-lembaga sosial yang efisien yang menghasilkan pembangunan ekonomi. Selain itu, pembangunan sosial juga dipahami sebagai pencapaian kualitas kehidupan yang diinginkan. Hal ini menunjukan bahwa pembangunan sosial mengacu pada pengembangan masyarakat secara keseluruhan (Samadha, Pandey, 2013).

Konsep pembangunan sosial juga sering dipertukarkan dengan konsep kesejahteraan sosial. Karena dalam konsep kesejahteraan sosial, kesejahteraan masyarakat tidak hanya di ukur dengan terpenuhinya kebutuhan dasar masyarakat (misalnya pendapatan, pendidikan, dan kesehatan), melainkan ketika masyarakat dapat mengelolah masalah-masalah sosial (misalnya kemiskinan, kriminalitas, dll) dan meningkatnya peluang masyarakat dalam berpartisipasi (Midgley dalam Adivar dkk, 2010). Untuk melakukan hal tersebut, maka dibutuhkan peningkatan kapasitas individu dan masyarakat. Dengan meningkatnya kapasitas individu dan masyarakat maka mereka akan mampu memenuhi kebutuhan dasar, mengelolah masalahmasalah sosial, dan mampu memaksimalkan peluang yang ada.

Seperti yang sudah di uraikan diatas, bahwa masalah kemiskinan di Kabupaten Nias Selatan merupakan masalah yang bersifat multidimensional. Untuk itu dalam mengentaskannya, diharapkan Pemerintah Kabupaten Nias selatan tidak hanya berfokus pada pembangunan ekonomi semata, melainkan pembangunan social juga harus di perhitungkan, karena pendekatan ini hadir sebagai respons atas kegagalan pembangunan ekonomi. Cox dan Pawar dalam Drolet dan Sampson (2014), mengemukakan bahwa pembangunan sosial merupakan sebuah pendekatan yang berpusat pada manusia, dimana kesejaht- 
eraan masyarakat lebih di utamakan ketimbang struktur dan system. Artinya, dengan meningkatkannya kemampuan individu, komunitas, dan masyarakat dipastikan kesejahteraan masyarakat secara keseluruhan akan terwujud.

Untuk mengentaskan masalah kemiskinan tidak boleh hanya menekankan pada pendekatan pembangunan ekonomi semata. Walaupun pembangunan ekonomi memiliki peran penting dalam mengentaskan kemiskinan, akan tetapi pembangunan ekonomi seringkali menuai kegagalan dalam menciptakan kesejahteraan rakyat banyak misalnya terjadi pengangguran, kesenjangan sosial, disintegrasi sosial, ketidakadilan sosial dan lain-lain. Hal ini disebabkan karena kemiskinan merupakan masalah yang bersifat multidimensional. Oleh karena itu, dalam mengentaskannya, pembangunan ekonomi harus bersinergi dengan pembangunan sosial, dimana pembangunan sosial bertujuan untuk meningkatkan kualitas individu, keluarga, dan masyarakat melalui pendidikan, kesehatan, jaminan sosial, partisipasi masyarakat, dan keadilan sosial. Dengan meningkatnya kemampuan individu, keluarga, dan masyarakat, maka akan berimplikasi pada kemandirian mereka dalam memenuhi kebutuhan dasar, mampu mengelolah masalah-masalah sosial, dan mampu memaksimalkan peluang yang ada.

Pemerintah di Kabupaten Nias Selatan melalui Dinas Sosial, sudah melakukan langkah yang strategis untuk menanggulangi kemiskinan masyarakat Untuk mendapatkan keberhasilan program layanan bantuan sosial di Dinas Sosial Kabupaten Nias Selatan, maka langkah strategis perlu memperhatikan apakah para pihak terkait telah memahami dan menjalankan maksud, tujuan, tugas serta fungsinya sebagaimana yang telah tertuang dalam aturan. Kedua, apakah tujuan dari program bantuan sosial tersebut merupakan upaya pengentasan kemiskinan di Kabupaten Nias Selatan telah dilaksanakan dengan baik atau belum.

Berdasarkan hasil wawancara, ditemukan bahwa para pihak terkait pelaksana program bantuan sosial sudah memahami bahwa program ini merupakan program strategis dalam percepatan pengentasan kemiskinan. Hal ini terbukti bahwa Dinas
Sosial Kabupaten Nias Selatan melalui pemerintahan di masing-masing desa dan kelurahan telah memberikan bantuan modal usaha secara tunai langsung kepada masyarakat miskin agar dapat mandiri dalam memenuhi kebutuhan secara ekonomi. Secara tekhnis standar dan tujuan pembentukan Kelompok Usaha Bersama cukup memudahkan penyelenggara untuk memahaminya, karena dibekali buku pedoman panduan teknis dari Kementrian Sosial tentang bagaimana pola rekruitmen, baik itu pendamping kelompok dan kelompok sasaran (fakir miskin), serta bagaiman menjalankan program ini.

Dalam pelaksanaan program Kelompok Usaha Bersama KUBE) yang jumlahnya di Kabupaten Nias Selatan masih 15 kelompok dari 150 kelompok yang di usulkan, semua kelompok yang terbentuk telah berkomitmen menjadi mitra pemerintah dalam menurunkan angka kemiskinan dan pelopor pengentasan kemiskinan di Kabupaten Nias Selatan, dimana sebelum membentuk kelompok, masyarakat melalui kelompok masing-masing terlebih dahulu merumuskan tujuan bersama kemudian tiap anggota yang tergabung wajib mengetahui tujuannya sebagai dasar langkah dalam merencanakan visi dan misi.

Pembentukan Kelompok telah didasari oleh tujuan yang jelas yang bersinergi dengan visi pemerintah daerah Kabupaten Nias Selatan dalam upaya pananggulangan kemiskinan. Konsep umum tujuan Kelompok Usaha Bersama (KUBE) yang disampaikan oleh kementrian Sosial, yang kemudian disampaikan kembali oleh Kepala Dinas Sosial Kabupaten Nias Selatan, yaitu: peningkatan kemampuan berusaha para anggota secara bersama dalam kelompok; peningkatan pendapatan; pengembangan usaha; dan peningkatan kepedulian dan kesetiakawanan sosial diantara para anggota Kelompok dan dengan masyarakat sekitar.

Disamping program Kelompok Usaha Bersama yang sudah terbentuk di Kabupaten Nias Selatan, berdasarkan hasil wawancara peneliti dengan Kepala Dinas Sosial sebagai informan kunci dalam penelitian ini, ibu Ritikasih Zagoto, SKM, MM selaku Kepala Bidang Pemberdayaan Fakir Miskin 
Kabupaten Nias selatan sebagai informan utama dalam penelitian ini, serta masyarakat yang mendapatkan bantuan sosial sebagai informan tambahan, bahwa salah satu bentuk bantuan sosial berupa beras yang disalurkan sebanyak 338,1 ton dengan penerima 33.810 KPM (Keluarga Penerima Manfaat) dari Cadangan Beras Pemerintah (CBP) untuk Program Keluarga Harapan (PKH) dan Bantuan Pangan Non Tunai (BPNT) maupun program Bantuan Sosial Tunai (BST) dengan sasaran 35 Kecamatan di wilayah Kabupaten Nias Selatan, meliputi sebanyak 15.596 KPM PKH, sebanyak 8.416 KPM BPNT/Sembako dan sebanyak 9.798 KPM BST yang tersebar di masing-masing kecamatan.

Pada tahun 2019 ada $13.000 \mathrm{KK}$ yang penerima PKH dan pada tahun 2020 naik menjadi $14.000 \mathrm{KK}$ dengan jumlah dana sekitar Rp 70 miliar. "Dana ini sama dengan tahun sebelumnya, hanya saja penerima manfaatnya bervariasi sesuai dengan ketentuan Kementerian Sosial. Kemudian beberapa program lainnya seperti Bantuan Sosial non tunai, dengan jumlah penerima sebanyak 28.954 kepala keluarga dengan nilai Rp. 150 ribu/bulan atau sekitar Rp. 52 miliar/tahun. Sebelumnya, bantuan sosial non tunai tersebut, cuma Rp 110.000/KK setiap bulannya. Disamping itu penanganan 26 masalah penyandang kesejahteraan sosial, dengan pemberian bantuan pangan seperti di Panti Asuhan, distabilitasi, Lansia terlantar, bencana alam dan sebagainya. Seterusnya, program Rehabilitasi Sosial Rumah Tidak Layak Huni (Rutilahu) jumlah penerima manfaat sebanyak 15 unit. Dan program Kelompok Usaha Bersama (KUBE) dari ratusan kelompok yang sudah diajukan di Kementerian, hanya 50 kelompok yang di setujui.

Berdasarkan hasil pengamatan peneliti dilapangan, bahwa langkah strategis penanganan masalah sosial dinas sosial di Kabupaten Nias Selatan telah terlaksana dengan baik melalui di beberapa kecamatan telah mendapat bantuan sosial yang disalurkan oleh Dinas Sosial kabupaten Nias selatan, dan dibuktikan oleh beberapa masyarakat melalui wawancara peneliti dengan masyarakat, sejalan dengan penelitian yang dilakukan oleh Dedy Utomo, dkk (2011) dalam penelitiannya yang berjudul
"Pelaksanaan Program Keluarga Harapan Dalam Meningkatkan Kualitas Hidup Rumah Tangga Miskin. Pelaksanaan Program Keluarga Harapan yang terdapat di Kecamatan Purwoasri ini didasarkan pada tingginya jumlah rumah tangga miskin. Hasil evaluasi membuktikan bahwa penerima PKH setiap tahunnya mengalami penurunan. Kesamaannya dengan yang dikaji peneliti saat ini adalah sama-sama mengkaji tentang kebijakan bantuan sosial $\mathrm{PKH}$, perbedaannya hanya lokasi penelitiannya berbeda.

Penelitian yang dilakukan oleh Habibullah (2011) di Kabupaten Karawang dengan judul "Peran Pendamping pada Program Keluarga Harapan Kabupaten Karawang" yang memberikan kesimpulan bahwa peran Pendamping sangat memberikan peran guna pelaksanaan PKH serta memberikan jaminan bagi penerima manfaat untuk selalu mengakses layanan pendidikan dan kesehatan. Selain itu perlu adanya pemberian capacity building bagi para Pendamping PKH dan peningkatan kesejahteraan melalui perbaikan honor yang diberikan. Penelitian dilakukan secara deskriptif. Persamaanya dengan penelitian yang sedang dikaji saat ini adalah samasama mengkaji tentang masyarakat miskin melalui pemberian bantuan PKH, perbedaannya adalah penelitian ini berfokus pada peran Pendamping PKH dalam tugasnya mendampingi Peserta PKH bukan pada langkah menjalankan kebijakan menangani masyarakat miskinya.

Fidyatun, (2012) dengan penelitiannya berjudul "Evaluasi Program Keluarga Harapan (PKH) Bidang Kesehatan Di Kabupaten Brebes Tahun 2011. Hasilnya Program Keluarga Harapan (PKH) bidang kesehatan di Kabupaten Brebes sudah berjalan dengan baik, hal ini dapat dilihat dari berjalannya program tersebut dengan baik di Kabupaten Brebes. Meskipun di awal program terjadi beberapa masalah dengan sektor kesehatan, namun sampai saat ini program tersebut sudah semakin baik dan mengalami perkembangan yang signifikan. Penelitian ini dilaksanakan di Dinas Sosial, Tenaga Kerja, dan Transmigrasi (Dinsosnakertrans) Kabupaten Brebes, Unit Pelaksana Program Keluarga Harapan (UPPKH) Kabupaten Brebes, dan Dinas Kesehatan (Dinkes) Kabupaten Brebes Obyek yang 
diteliti adalah kelembagaan, kepesertaan, pembiayaan, dan pemberi pelayanan kesehatan (PPK). Subyek dalam penelitian ini adalah Kepala Dinsosnakertrans, Pemegang program PKH, Dinas Kesehatan, dan Koordinator UPPKH Kabupaten. Teknik pengambilan sampel yang digunakan dalam penelitian ini yaitu diambil dengan menggunakan purposive sampling. Syarat pemilihan informan yaitu yang berhubungan langsung pelaksanaan PKH. Jumlah informan utama ada 3 orang yaitu kepala Dinas Sosial, Tenaga Kerja, dan Transmigrasi (Dinsosnakertrans) Kabupa-ten Brebes yang diwakilkan oleh sekretaris, Kordinator Unit Pelaksana Program Keluarga Harapan (UPPKH) Kabupaten Brebes, dan Dinas Kesehatan (Dinkes) Kabupaten Brebes. Uji validitas yang digunakan adalah triangulasi sumber yang terdiri dari 5 orang yaitu Pendamping PKH, Bidan Desa, dan Kepala Desa.

Penelitian Usman, (2014) berjudul "Efektivitas Program Keluarga Harapan (PKH) dalam Rangka Penanggulangan Kemiskinan (Suatu Studi di Kecamatan Kota Utara Kota Gorontalo)". Hasil penelitian menunjukkan bahwa responden berpendapat di Kecamatan Kota Utara Kota Gorontalo tentang efektivitas Program Keluarga Harapan (PKH) rata-rata di kategori sedang atau moderat, yaitu 46,7\% dari 90 responden, sedangkan dalam kategori rendah adalah 23,3\% dari responden, dan dalam kategori tinggi hanya sekitar $19,1 \%$, sedangkan untuk penanggulangan kemiskinan rata-rata berada di kategori sedang adalah $48,9 \%$ sedangkan pada kategori rendah yaitu $14,4 \%$ dari 13 responden dan kategori tinggi sekitar $36,7 \%$. Hasil penelitian ini berhasil menguji hipotesis yaitu efektivitas program keluarga harapan berpengaruh positif dan signifikan dalam menanggulangi kemiskinan di Kecamatan Kota Utara Kota Gorontalo.

\section{SIMPULAN DAN SARAN}

\section{A. Simpulan}

Berdasarkan uraian hasil penelitian dan pembahasan, dapat ditarik kesimpulan sehubungan dengan permasalahan penelitian yang diajukan sebagai berikut:

1. Dari hasil penelitian dilapangan bahwa langkah yang dilaksanakan Dinas Sosial
Kabupaten Nias Selatan dalam Program bantuan sosial yang berasal dari pemerintah termasuk bantuan untuk Program Keluarga Harapan (PKH), Kelompok Usaha Bersama (KUBE) dan bentuk bantuan Sosial lainya selalu mendapat dukungan yang baik dari berbagai pihak masyarakat di Kabupaten Nias Selatan, meski belum maksimal dan masih banyak kekurangan yang perlu diperbaiki. Hal ini terlihat dari sebagian kelompok sasaran yang masih belum tepat, jumlah pelaksana yang terbatas dari segi kuantitas sehingga belum bisa dikatakan maksimal.

2. Struktur birokrasi di Dinas sosial kabupaten Nias Selatan masih terkendala dalam bentuk aspek fragmentasi sehingga membutuhkan partisipasi aktif dari semua pihak yang terlibat baik itu masyarakat yang menjadi sasaran bantuan maupun pelaksana program dari Dinas Sosial Kabupaten Nias Selatan dan Desa sebagai eksekutor dilapangan.

\section{B. Saran}

Selanjutnya dapat disarankan sebagai berikut:

1. Perlu adanya pendataan terbaru mengenai data fakir miskin di Kabupaten Nias Selatan untuk tiap tahunnya, agar pemerintah lebih mudah dalam mengambil kebijakan dan bisa mengevaluasi apakah sudah tepat sasaran atau tidak.

2. Perlu agar lebih memanfaatkan sarana informasi yang ada untuk mengakses dan memberikan data informasi yang transparansi agar bisa diperoleh dan diketahui oleh pemerintah itu sendiri dan masyarakat.

3. Perlu segera diterbitkan SOP sebagai inti di dalam suatu lembaga ataupun instansi pemerintahan agar nantinya dapat dijadikan sebagai suatu pedoman dalam setiap adanya pelaksanaan penyaluran bantuan sosial.

\section{DAFTAR RUJUKAN}

Aminatun, 2017. Peran Keluarga Dalam Peningkatan Kesejahteraan Sosial Anak Melalui Program Keluarga Harapan. Media Informasi Penelitian Kesejahteraan Sosial,Volume 40 Nomor 3 Desember 2016. Halaman 243-254.

Arikunto, Suharsini. 2005. Menejemen Penelitian. Jakarta. PT. Rineka Cipta. Asmawati, Fikriyah. 2014. Evaluasi Pelaksanaan Program Bantuan Langsung 
Ayal, Lidia Nugrahaningsih. 2016. Penanganan Kemiskinan Melalui Kelompok Usaha Bersama (KUBE) Studi Kasus di Kota Banjarmasin. Media Informasi Penelitian Kesejahteraan Sosial,Vol.40,No.2,Agustus 2016.177-190

Azriah, Thahrina. 2015. Evaluasi Dampak Program Keluarga Harapan dalam Upaya Pencapaian Mellenium a Development Goals di Desa Jeruklegi Kulon Kecamatan Jeruklegi. Tesis. Universitas Jenderal Soedirman.

Debora, Hemi Manongko. 2016.Implementasi Kebijakan Program Keluarga Harapan Di Kecamatan Belang Kabupaten Minasaha Tenggara. Jurnal Eksekutif Vol 1, No 7

Dedy, Utomo, Abdul Hakim, Heru Ribawanto.2011. Pelaksanaan Program Keluarga Harapan Dalam Meningkatkan Kualitas Hidup Rumah Tangga Miskin (Studi pada Unit Pelaksana Program Keluarga Harapan Kecamatan Purwoasri, Kabupaten Kediri). Jurnal Administrasi Publik (JAP), Vol. 2, No. 1, Hal. 29-34.

Evi Rahmawati, Bagus Kisworo. 2017."Peran Pendamping dalam Pemberdayaan Masyarakat Miskin melalui Program Keluarga Harapan". Journal of Non formal Education and Community Empowerment. Volume 1 (2): 161-169.

Fidyatun, Erna. 2012. Evaluasi Program Keluarga Harapan (PKH) Bidang Kesehatan Di Kabupaten Brebes Tahun 2011. Jurnal Kesehatan Masyarakat, Volume 1, Nomor 2, Tahun 2012, Halaman 26 - 36

Febrina. Ghina 2016. Analisis Pelaksanaan Program Keluarga Harapan Di Kabupaten Brebes Tahun 2014.

Gustina, Indah. 2008. Implementasi Program Penanggulangan Kemiskinan di Perkotaan (P2KP) di Kecamatan Medan Maimun dalam repository.usu.ac.id/bitstream/123456789/ 7102/1/057024035.pdf. Tesis Universitas Sumatera Utara

Habibullah. 2011. Peran pendamping pada program keluarga harapan kabupaten karawang. Jurnal Informasi (Kajian Permasalahan Sosial Dan Usaha Kesejahteraan Sosial), 16(2), 101-116
Hidayatullah, A. Nururrochman. 2016. Implementasi Kelembagaan Program Keluarga Harapan Dalam Kebijakan Perlindungan Sosial Bagi Keluarga Miskin (Studi Implementasi Kelembagaan UPPKH di Kabupaten Bantul Daerah Istimewa Yogyakarta).Tesis.Magister Pembangunan Sosial dan Kesejahteraan. Universitas Gadjah Mada.

Laluhang, Sri Masita. 2014. Implementasi Program Keluarga Harapan (PKH)Dalam Rangka Penanggulangan Kemiskinan Di Desa Kendahe IIKecamatan Kendahe Kabupaten Sangihe, E jurnal Unsrat, di akseshttp//:ejournal.unsrat.ac.id/index.ph p/ jurnaleksekutif, pada 15 Maret 2015.

Laoh,Stevianus, dkk. 2016. Evaluasi Proses Bantuan Program Keluarga Harapan (PKH) Di Kelurahan Malalayang Satu Kecamatan Malalayang Kota Manado. Agri-Sosio Ekonomi Unsrat, ISSN 1907- 4298 , Volume 12, Nomor 2A, Juli 2016 : 315 330.

Lidiana,Mohd.Nursyechalad, Muhammad Nasir. 2014. Pengaruh Dan Efektifitas Bantuan Program Keluarga Harapan (PKH) Terhadap Partisipasi Pendidikan Di Kecamatan Muara Tiga Kabupaten Pidie. Jurnal Ilmu Ekonomi ISSN 23020172.Pascasarjana Universitas Syiah Kuala.ISSN 2302-0172.Volume 2, No. 2, Mei 2014.

Maharani, Elsa Rizki dan Rusdarti .2017. Implementasi Kebijakan Distribusi Program Raskin Di Desa Kawengen Kabupaten Semarang. Economic Development Analysis Journal.Vol,6.N0.4. 2017.Halaman 451-457

Milles, Mattew. 1992. Analisa Data Kualitatif. Buku Sumber Tentang Metode metode Baru. Jakarta. Universitas Indonesia Press.

Moleong, Lexy J. 2006. Metodologi Penelitian Kualitatif. Bandung. PT. Remaja Rosdakarya.

Nainggolan, Togiaratua, dkk. 2012. Program Keluarga Harapan di Indonesia: Dampak Pada Rumah Tangga Sangat Miskin di Tujuh Provinsi, P3KS Press. 
Nurmiza, dkk. 2014. Implementasi Program Bantuan Langsung Sementara Masyarakat(BLSM) Tahun 2013 di Kelurahan Kampung Baru Kecamatan TanjungPinang Barat. Universitas Maritim Raja Ali Haji.

Nugroho, Riant. 2009. Public Policy. Jakarta. PT. Elex Media Komputindo. Puspita, dita wahyu. 2015. "Analisis Determinan Kemiskinan di Provinsi Jawa Tengah". JEJAK Journal of Economics and Policy. Jejak 8 (1) (2015): 100-107

Purwanto, Erwan Agus dkk. 2012. Implementasi Kebijakan Publik, Konsep danAplikasinya di Indonesia. Yogyakarta . Gava Media.

Riyadi, Slamet . 2016. Analisis Implementasi Program Keluarga Harapan (PKH) Terhadap Keluarga Sangat Miskin (KSM) Penerima Bantuan (Studi di Kecamatan Gunung Sugih Kabupaten Lampung Tengah)". Tesis. Program Studi Magister Ilmu Pemerintahan Fakultas Ilmu Sosial dan Ilmu Politik Universitas Lampung. BandarLampung.

Rusdarti, Lesta Karolina Sebayang. 2013. FaktorFaktor yang Mempengaruhi Tingkat Kemiskinan di Provinsi Jawa Tengah. Jurnal Economia Volume 9, Nomor 1, April 2013

Rusmiyati, Chatarina dan Ahkmad Purnama. 2016.Analisis Kebutuhan Pelayanan Sosial bagi Keluarga Nelayan Miskin. Jurnal PKS Vol.15 No.3 September 2016; 219-234

Sahib, Munawwarah. 2016. Pengaruh Kebijakan Program Keluarga Harapan terhadap Penanggulangan Kemiskinan di Kecamatan Bajeng Kabupaten Gowa. Tesis. Ekonomi Islam. Program Pascasarjana Universitas Islam Negeri Alaudin Makassar

Subarsono, AG. 2016. Analisis Kebijakan Publik. Konsep, Teori, dan Aplikasi. Yogyakarta. Pustaka Pelajar.

Sugiyono. 2016. Memahami Penelitian Kualitatif. Bandung: Alfabeta.

\footnotetext{
Suharto, Edi. 2010. Membangun Masyarakat Memberdayakan Rakyat. Bandung.PT. Refika Aditama.
}

Suharto, Edi. 2013. Kemiskinan dan Perlindungan Sosial di Indonesia, Menggagas Model Jaminan Sosial Universal Bidang Kesehatan. Bandung. Alfabeta.

Suwinta,Antriya Eka dan Indah Prabawati. 2016. Implementasi Program Keluarga Harapan (PKH) Di Desa Maron Kecamatan Kademangan Kabupaten Blitar.Kajian Kebijakan Publik. Volume 1 Nomor 1 Tahun 2016, 0-216.

Teddy Christianto, 2013. Determinan dan karakteristik kemiskinan di provinsi Riau Volume VII, No. 2, Desember 2013 ISSN : 1978 - 3612.

Tobirin, Slamet Rosyadi. 2010. Perumusan Kebijakan Publikdalam Menggali Akar Kemiskinan.Jurnal Ilmu Administrasi Negara, Volume 10, Nomor 2 Juli 2010:114-125.

Wrihatnolo, Randy R, dkk. 2002. Manajemen Pemberdayaan, Sebuah Pengantar dan Panduan untuk Pemberdayaan Masyarakat. Jakarta. PT. Elex Media Komputindo.

\section{Peraturan Perundang-undangan}

Inpres No 3 Tahun 2010 tentang Rencana Tindak Percepatan Pencapaian Sasaran Program Pro-Rakyat.

Pasal 32 Peraturan Menteri Sosial Nomor 1 Tahun 2018 Tanggal 8 Januari 2018 tentang Program KeluargaHarapan.

Peraturan Presiden Republik Indonesia Nomor 15 Tahun 2010 tentang Percepatan Penanggulangan Kemiskinan.

\section{Data Lain-Lain}

Badan Pusat Statistik, 2009. "Berita Resmi Statistik Jawa Tengah". Jawa Tengah. Badan Pusat Statistik, 2017."Kabupaten Brebes Dalam Angka"

Badan Pusat Statistik, 2017."Kecamatan Bulakamba Dalam Angka".

Badan Pusat Statistik, 2017."Provinsi Jawa Tengah Dalam Angka". Melalui jateng.bps.go.id diakses 24 Maret 2018. 